\title{
The Effect of Tax Knowledge, Reward, and Enforcement Strategies on SMEs Tax Compliance Behavior
}

\author{
[ I Putu Fajar Dipayana Putra ${ }^{1}$, Amrie Firmansyah ${ }^{2}$ ]
}

\begin{abstract}
This research is aimed at providing empirical evidence on the effect of tax knowledge, reward, and enforcement strategies on SMEs tax compliance. Small and Medium Enterprises (SMEs) tax compliance on the islands of Bali and Lombok is low due to the imbalance between their low tax revenue contribution with the percentage of the total SME registered to entire business that reached $\pm 97 \%$. This study is quantitative research using primary data. Using purposive sampling, this study selects 201 SMEs that are located in Bali and Lombok island as samples. The examination uses the multiple regression analysis. The study suggests that, except the deterrence approach of enforcement strategies, all independent variable used in this study have the positively significant correlation on SMEs tax compliance level.

Keywords- tax compliance, tax knowledge, reward, enforcement strategies, SMEs
\end{abstract}

\section{Introduction}

Based on the data from www.kemenkeu.go.id, Indonesia's tax ratio from 2012 to 2016 tends continues to decline. Declining tax ratio indicates that Indonesia's GDP growth rate from 2012 to 2016 is not in line with the growth rate of tax revenues. One of the common problems causing the continued decline of tax ratio is the low level of tax compliance in Indonesia. Indonesia's Minister of Finance discloses the fact that the lowest tax compliance level is seen in Small and Medium Enterprises (SMEs) (Rachman, 2017). The fact is supported by Assistant Deputy of Non-Bank Financing and Taxation of the Ministry of Cooperatives and SMEs which revealed that only 397 thousand SMEs who pay taxes from the total of 59 million SMEs or only $0.7 \%$ of SMEs are aware of paying taxes (Sawitri, 2017b).

To provide an understanding of the tax regulations of SMEs, Indonesia Tax Office especially Regional Offices routinely organized dissemination, tax training, and visiting the taxpayer. However, many activities such as dissemination, tax training, and visiting tend to increase every year, but such activities do not have a significant impact on the increase in

\footnotetext{
${ }^{1}$ Directorate of Tax Potential, Compliance, and Revenue Directorate General of Taxes

Jend. Gatot Subroto Street No. 40-42 Jakarta, Indonesia, 12190

${ }^{2}$ Department of Accounting

Polytechnic of State Finance STAN

Bintaro Main Street $5^{\text {th }}$ Sector, Bintaro Jaya, South Tangerang, Banten, Indonesia, 15222
}

tax revenue in the SMEs sector. According to Kirchler et al. (2006), the taxpayer has a high intention to report on time and correct if the taxpayer has a high tax knowledge. Also, Oladipupo and Obazee (2016) argue that tax knowledge tends to increase tax compliance compared to penalties. The existence of the gap as described above is the main concern of this study to determine the effect of tax knowledge on tax compliance of SMEs in Indonesia. This study adds some components of general tax knowledge in addition to specific tax knowledge which has not been used on related research in Indonesia.

Also, Bornman and Stack (2015b) state that reward systems have a positive effect on taxation behavior of small business owners. This opinion is also supported by Carillo et al. (2016), who find that rewards have a positive effect on tax compliance on taxpayers who won the lottery prizes. Bornman and Stack (2015a) also suggest similar research results; rewards have a positive impact on tax compliance. However, Fochmann and Kroll (2015) have a different finding, that rewards have no effect on tax compliance from taxpayers who are rewarded and have a negative effect on tax compliance from taxpayers who are not rewarded. Also, Brockmann et al. (2016) also support the results of the research of Fochmann and Kroll (2015) which reveal that the positive reward does not affect the overall tax compliance level. Currently, Indonesia Tax Office has never had a reward program applied simultaneously and consistently to all taxpayers, especially SMEs. So, it is essential for the Indonesian tax office to know through this research whether rewards can be used as an alternative solution in improving SMEs tax compliance or not.

Based on the literature review, the use of reward variable in explaining the tax compliance behavior in Indonesia is only conducted by Iskandar and Andriani (2017) with the method of experimental research time series design, while the use of variables enforcement strategies in explaining tax compliance in Indonesia especially SMEs has not been conducted. The reward variable used in this study differs from that of Iskandar and Andriani (2017) and slightly modifies the reward variables in Bornman and Stack (2015b) research. The modification is the form of replacement of lottery reward with a recommendation to ease banking credit, such as a more considerable ceiling, faster disbursement, and loosen some requirement of credit application. The replacement considers the results of a study from the Central Bank of Indonesia (2015) which states that $60 \%-70 \%$ of SMEs in Indonesia are experiencing financing problems to develop the business so that reward in the form of a recommendation to ease banking 
credit will be more relevant. Another form of reward in the Bornman and Stack (2015b) study, i.e. compliance certificates and mass media publications are still used in this study considering such rewards can increase intrinsic motivation according to motivation crowding theory.

Besides rewards, a definite step in improving compliance of SMEs taxpayers is undoubtedly by enforcing the law against tax rules related to SMEs, namely Government Regulation No. 46 of 2013. Up until now, Indonesia Tax Office is considered as less effective in the implementation of law enforcement against the SMEs taxpayers. The ineffectiveness is seen from the lack of participation of SMEs in contributing to developing the country through paying taxes. Whereas, the contribution of the SMEs sector to Indonesia's GDP is at a fantastic figure, which is $60 \%$ (Chandra, 2016). In relation to the effectiveness of law enforcement, Murphy (2008) argues that there has been a long debate over the effectiveness of law enforcement strategies that can be divided into two approaches, namely deterrence approach (investigation, and strengthening of uncompromising tax assessment letters) and an accommodative approach (appealing to taxpayers, visits, consultations, and persuasiveness). Meanwhile, research in Indonesia has never tested which law enforcement approaches are more effective in improving tax compliance of SMEs taxpayer. Therefore, this study is aimed to examine which strategy is more effective in improving tax compliance of SMEs in Indonesia.

This research uses research sample in Bali and Lombok as a representation of Nusa Tenggara region considering that majority of SMEs in Nusa Tenggara is on Lombok island with the percentage of $42 \%$ based on BPS Economic Census in 2016. Based on data obtained from Indonesia Regional Tax Office of Bali and Nusa Tenggara, the percentage of SMEs tax payment on total tax revenue on Bali and Lombok in 20142016 is very low, which is only about $\pm 1 \%$. The low contribution of SMEs taxes in Bali and Lombok is inversely proportional to economic growth in Bali and Nusa Tenggara which in 2015 is ranked highest in Indonesia and 2016 is ranked third with an economic growth rate above the national average. The high economic growth in Bali and Nusa Tenggara in 2015 and 2016 do not provide a significant increase to tax revenues in the SMEs sector in 2015 and 2016, but based on the Economic Census of the Central Bureau of Statistics 2016, the economy of Bali and Nusa Tenggara are primarily supported by SMEs.

\section{Hypotheses Development}

\section{A. Tax Knowledge}

One of the determinants of behaving intent in the theory of planned behavior is behavioral beliefs. Behavioral beliefs explain the individual's faith in the outcomes of a response and the evaluation of the outcomes. This factor explains that before doing something, the individual has a belief in the outcomes obtained from the behavior so that it will decide whether to do or not. Previous researches that have been done by Oladipupo and Obazee (2016), Redae and Sekhon (2016), Saad (2014), and Palil (2010, 2013) on tax knowledge variables found similar research results. They generally stated that tax knowledge had a positive effect towards tax compliance. The similar study that also conducted on SMEs in Indonesia such as Mir'atusholihah (2014), Suntono and Kartika (2015), Purnaditya et al. (2015), Masruroh and Zulaikha (2015), and Ananda (2015) states that the knowledge/understanding of taxes has a significant positive effect on the SMEs compliance in Indonesia. It suggests that taxpayers who have high tax knowledge allegedly will bring a sense of awareness that taxes paid by taxpayers are important for the development of Indonesia. This awareness gives rise to believe in the importance of contributing through tax payments for the outcomes of Indonesia's development, such as infrastructure, health, education, and so on. Based on the above description, the first hypothesis in this study stated as follows.

H1: Tax knowledge (TaxKnow) is positively associated with SMEs tax compliance (Comp).

\section{B. Reward}

Based on social learning theory, taxpayers will imitate another taxpayer compliant behavior by first considering some meditational processes. One of the types of meditational methods introduced in social learning theory is motivation. Also, one of the determinants of people intentions in the theory of planned behavior is normative beliefs which means there is a motivation to fulfill an expectation.

Based on research by Carillo et al. (2016), the positive reward, in particular, winning the lottery has a positive relationship to tax compliance and taxpayers recognized by the government by publishing to the mass media also has a positive effect on tax compliance. Finally, the chance of winning the lottery has a positive effect on short-term tax compliance while the rewards of road sidewalk development at the taxpayer's location have a positive effect on long-term compliance. Bornman and Stack (2015) using reward rewards and certification/compliance publications found the use of both strategies has a positive effect on taxpayer compliance in South Africa. Brockmann et al. (2016) and Fochmann and Kroll (2015) state different things from the results of his research that rewards have no significant effect on tax compliance and the positive reward gives a negative effect on tax compliance for taxpayers who do not get rewards.

Reward in this research uses the recommendation to ease banking credit (monetary reward) because the central problem of SMEs in conducting its business is financing, while the primary consideration of using reward in the form of compliance certificate/mass media publication (nonmonetary reward) because the reward will increase the intrinsic motivation of the taxpayer to comply. Reward allegedly included in the category of motivation in social learning theory and also included in the normative beliefs in the theory of planned behavior because the reward will bring the desire or motivation of taxpayers to conduct comply/ respectful behavior towards taxation regulations. Therefore, the second and third hypotheses in this study are as follows. 
H2: Reward in the form of a recommendation to ease banking credit $($ RewM) is positively associated with SMEs tax compliance (Comp).

H3: Reward in the form of compliance certificate/mass media publication (RewNM) is positively associated with SMEs tax compliance (Comp).

\section{Enforcement strategies}

One of the decisive factors that give rise to the intention of behaving in the theory of planned behavior is the control beliefs. Control beliefs explain the existence of things that support or hinder the response that will be displayed. Also, control beliefs also explain the perception of how strong elements support and inhibit individual behavior. Murphy (2008) investigates two types of enforcement strategies, a deterrence and accommodative approach that suggests that both strategies have a positive effect on tax compliance, but in that research, the accommodative approach has a more significant positive effect than the deterrence approach. A similar study is also conducted by Ortega and Sanguinetti (2013) who examine the effectiveness of enforcement and moral suasion in increasing tax compliance. The study explains that the message conveyed with enforcement tones has greater effect on tax compliance as compared to messages conveyed in a moral suasion tone. Law enforcement allegedly included in the category of control beliefs because law enforcement is an Indonesia Tax Office effort to inhibit the behavior of taxpayer non-compliance with the tax laws. Therefore, the fourth and fifth hypotheses in this study are as follows.

H4: Law enforcement in the form of deterrence approach (Deter) is positively associated with SMEs tax compliance (Comp).

H5: Law enforcement in the form of accommodative approach (Accom) is positively associated with SMEs tax compliance (Comp).

\section{Research Methodology}

The research method used in this study is a quantitative method. Multiple linear regression is performed, and a multiple regression model of research variables can be arranged with the following functions/equations.

\section{Comp $=\alpha+\beta 1$ Taxknow $+\beta 2 \operatorname{RewM}+\beta 3 \operatorname{RewNM}+$ $\beta 4 D e t e r+\beta 5 A c c o m+\varepsilon$}

This study uses primary data which is gotten by direct survey results using questionnaires to SMEs taxpayers in Bali and Lombok. The population is a taxpayer of SMEs in Bali and Lombok with a gross annual turnover of Rp 4.8 Billion so that the taxpayer must meet the tax obligations by Government Regulation No. 46 of 2013. This study uses purposive sampling techniques with the selection of SMEs respondents under the criteria of Government Regulation No. 46 of 2013 (having a yearly turnover equal to or less than Rp4.8 billion and excludes the street vendors type of business).
This research was conducted by distributing as many as 216 questionnaires to the SMEs taxpayer. The dependent variable used in this study is tax compliance behavior. Tax compliance according to James and Alley (2002) is a level that describes the extent to which taxpayers abide by the rules of taxation. The dependent variable of the tax compliance behavior in this study modified the compliance component on the Murphy et al. (2016) research questionnaire. The variable is adjusted with the conditions in Indonesia and being added with some components of formal tax compliance in Indonesia. While there are five independent variables in this study, namely Reward in the form of a recommendation to ease banking credit (RewM), Reward in the form of compliance certificates/mass media publications (RewNM), deterrence approach (Deter), accommodative approach (Accom), and tax knowledge (TaxKnow).

Meanwhile, reward in the context of this research is a real or unreal incentive that is managed by the tax authority to encourage voluntary taxpayer compliance (Bornman 2014 in Bornman and Stack 2015b). This reward variable uses two reward options, namely recommendation to ease banking credit and compliance certificate/mass media publication. The indicator for this variable is based on a modified statement in the Bornman and Stack (2015b) research and being adjusted with the conditions in Indonesia. Tanko (2015) defines enforcement, the act of ensuring that people comply with specific laws or regulations; or action to make sure something happens or to force someone to do something. The independent variables of enforcement strategies use two approaches: deterrence and accommodative approaches. Indicators for this variable are based on a modified statement in the Murphy (2008) and Murphy et al. (2016) research questionnaire by adjusting conditions in Indonesia. Oladipupo and Obazee (2016) define tax knowledge, i.e., the level of awareness or sensitivity of taxpayers to tax regulations. In this study other than specific knowledge about taxation rules for SMEs, this tax knowledge variable also contains a statement about the general tax knowledge such as the role of tax for development in Indonesia. The indicators for this variable are based on empirical facts about general tax knowledge and some of the main points in Government Regulation No. 46 of 2013.

\section{Result}

This research is conducted by distributing as many as 216 questionnaires to the SMEs taxpayer. Of that number, questionnaires considered valid for the research sample amounted to 201 questionnaires (rate of return 93.05\%). Before hypothesis examining is conducted, validity test and reliability test are led to construct variable of reward, enforcement strategies, and tax knowledge. The validity test performed suggests that all construct statements of the variables used in this study are valid because they have the value of $r$-value $>r$-table at $95 \%$ confidence level. The results of the reliability test yield the Cronbach Alpha $(\alpha)$ value, and the result of all variables used in this study has Cronbach Alpha $(\alpha)$ higher than the limit according to Nunnally (1994) in Ghozali (2016) is 0.70 . 
Descriptive statistics of respondent's answers to each of the research variables is presented as follows

Table 1

Descriptive Statistics

\begin{tabular}{|c|c|c|c|c|r|}
\hline Variable & N & Min & Max & Mean & Std. Deviation \\
\hline RewM & 201 & 1.00 & 5.00 & 3.7973 & .77355 \\
\hline RewNM & 201 & 1.00 & 5.00 & 3.6443 & .77642 \\
\hline Deter & 201 & 1.00 & 4.67 & 2.0663 & .81956 \\
\hline Accom & 201 & 2.00 & 5.00 & 3.9066 & .66294 \\
\hline TaxKnow & 201 & 1.46 & 5.00 & 3.2121 & .65067 \\
\hline Comp & 201 & 1.57 & 5.00 & 3.6289 & .60554 \\
\hline
\end{tabular}

Source: Processed

Based on these descriptive statistics, the provision of rewards for taxpayers who adhere to the regulations of taxation gain enough support from the research respondents. The support can be seen from the average score for the two reward options that have an average value above 3 . If comparing the average value of the two reward options available, the reward in the form of a recommendation to ease banking credit (RewM) is more favored by the research respondent than rewards in the form of certification of compliance and mass media publication (RewNM). Meanwhile, the enforcement strategies between deterrence and accommodative approaches have significantly different mean values. The average, minimum, and maximum values provide enough illustration that the study respondents do not like the law enforcement conducted by the Indonesia Tax Office is deterrence and respondents prefer the accommodative law enforcement approaches rather than the deterrence approach. Tax knowledge and tax compliance behavior have a value above 3 , which means the respondents have sufficient tax knowledge and tendency to comply with tax regulations.

Furthermore, based on Table 2., it can be seen that the adjusted value $\left(\mathrm{R}^{2}\right)$ is 0.522 or $52.2 \%$. This value indicates that the variation of tax compliance behavior can be explained by the independent variable in the research model by $52.2 \%$ while the rest of $47.8 \%$ is explained by other factors outside the research model. Thus, it can be concluded that the ability of independent variables is secure enough in describing the dependent variable in this research model.

Table 2

Determination Coefficient Test (R2)

\begin{tabular}{|c|c|c|c|c|}
\hline Model & $\mathrm{R}$ & $\mathrm{R}$ Square & Adjusted R Sq & Std. Err of the Est. \\
\hline 1 & 0.731 & 0.534 & 0.522 & 0.41853 \\
\hline
\end{tabular}

Source: Processed

Meanwhile, based on table 3, it can be seen that Sig (Fstatistic) has a value of 0.000 so smaller than the significance limit $(\alpha)$ of 0.05 . F-statistic value based on table 3 below is equal to 44,732. The F-statistic value must be compared with the $\mathrm{F}$ value according to the table. The value of $\mathrm{F}$ table is 2.2604. When being compared, the F-statistic value of 44.732 is much larger than the F-table which is only 2.2604. So it can be concluded that simultaneously independent variables consisting of tax knowledge (TaxKnow), rewards in the form of recommendation to ease banking credit (RewM), rewards in the form of certification of compliance/publication of mass media (RewNM), deterrence approach (Deter) and accommodative approach (Accom) have an effect on the dependent variable, namely tax compliance behavior (Comp).
Table 3

F-Test

\begin{tabular}{|r|l|r|r|r|r|r|}
\hline \multicolumn{2}{|c|}{ Model } & Sum of Squares & df & Mean Sq. & F & Sig. \\
\hline 1 & Regression & 39.178 & 5 & 7.836 & 44.732 & .000 \\
\hline & Residual & 34.158 & 195 & 0.175 & & \\
\hline & Total & 73.335 & 200 & & & \\
\hline
\end{tabular}

Source: Processed

Lastly, the t-Test in table 4 aims to show how far the influence of one independent variable individually describes the variation of the dependent variable used in the regression equation model. The result of t-test conducted on the model of regression equation in this study with a confidence level $(\alpha)$ of $5 \%$ can be seen in table 4 below.

$$
\text { Tabel } 4
$$

t-Test

\begin{tabular}{|c|r|r|r|r|c|}
\hline Variable & Expected & Coeff. & \multicolumn{1}{c|}{ t } & Sig. & Hipotesis \\
\hline RewM & + & 0.134 & 2.879 & 0.004 & Accepted \\
\hline RewNM & + & 0.11 & 2.306 & 0.022 & Accepted \\
\hline Deter & + & 0.018 & 0.46 & 0.646 & Rejected \\
\hline Accom & + & 0.198 & 4.119 & 0.000 & Accepted \\
\hline TaxKnow & + & 0.432 & 7.904 & 0.000 & Accepted \\
\hline
\end{tabular}

Source: Processed

\section{A. Tax knowledge and tax compliance}

Based on the theory of planned behavior, tax knowledge plays a role in generating beliefs in the taxpayer about the outcome in the form benefit of tax paid. Once the beliefs appear in the taxpayer, the taxpayer will decide to have the intention to comply with the tax law which will later be transformed into compliance behavior with the rules of taxation (behavioral beliefs). The results of this study are in line with the study of Oladipupo and Obazee (2016) in Nigeria that reveals that tax knowledge has a better tendency in improving SMEs tax compliance compared to penalties. Also, the study that is conducted by Palil $(2010,2013)$ in Malaysia also find similar results. The study states that tax knowledge has a positive effect on tax compliance. Another research outside Indonesia using different methods such as Redae and Sekhon (2016) and Saad (2014) studies also obtained similar results, for example, the factors that caused non-tax compliance was the inadequacy of tax knowledge from taxpayers which caused taxpayers to be lazy in complying with regulatory requirements taxation.

The results of this study are also in line with studies in Indonesia, such as Mir'atusholihah (2014), Suntono and Kartika (2015), Purnaditya et al. (2015), Masruroh and Zulaikha (2015) and Ananda (2015) who also conducts research using variable knowledge of taxation (tax knowledge) to tax compliance. The studies in Indonesia also show the result that the understanding of taxation (tax knowledge) has a positive effect on tax compliance. However, the difference of this study with the other research in Indonesia that uses the variable of tax understanding (tax knowledge) is tax knowledge variable used for other research in Indonesia only consists of specific tax knowledge, whereas this study also uses the components of general tax knowledge instead of only using the particular tax knowledge. 
Based on data from the Regional Tax Office of Bali and Nusa Tenggara, dissemination related to taxes have been routinely conducted every year. However, the efforts undertaken by the Regional Tax Offices especially in Bali and Lombok do not have a significant effect in increasing the tax revenue of SME's sector. Comparing the results of the research with the efforts of Regional Tax Office, it is suspected that there is a problem in the process of providing tax knowledge conducted by the Indonesia Tax Office especially in Bali and Lombok.

Reviewing from the content of dissemination materials or leaflets for SMEs taxpayers provided on the website www.pajak.go.id, it is almost no component of general tax knowledge such as an understanding of the role of taxes for development, the role of SMEs on development through taxes, the relationship between low tax revenues on state debts. Regarding this study, tax knowledge that can improve tax compliance of SMEs is tax knowledge consisting of general tax knowledge and specific tax knowledge of taxation. Also, Mukasa (2011) also states that enhancing general tax knowledge by including into the content of socialization or leaflet can improve taxpayer compliance. Increasing tax compliance is due to the positive perception of SMEs taxpayers on the tax that has been paid. Also, the reason why improving tax knowledge process less useful to the SMEs taxpayers is the level of education of the SMEs taxpayers are very low (mostly only educated elementary to high school). Whereas, the education is an essential factor in the understanding of tax knowledge that will ultimately lead to the level of compliance of the taxpayer concerned.

\section{B. Rewards and tax compliance}

The result of this study is relevant with Bornman and Stack (2015b) which reveal that reward systems can have a positive effect on taxation behavior of small business owners and most of the reasons that support such mechanisms are those that have motivational value. Fatas et al. (2015) also add that increased compliance in paying taxes occurs if such activities provide social returns to taxpayers. It means that if the taxpayer does not feel something of his actions to pay taxes, the taxpayer would be reluctant to pay taxes in the future. The same result is also found by Carillo et al. (2016) stating that visible and durable rewards have a significant positive effect on long-term tax compliance.

The result of this study is in line with the theory of planned behavior because the reward in the form of a recommendation to ease banking credit (RewM). Also, rewards in the form of compliance certificates/mass media publications (RewNM) is considered one of the incarnations of normative beliefs which is one of the factors that determine the intention of behaving from individuals. The reward will provide its motivation for taxpayers to comply with the provisions of taxation. In addition, the reward in the form of a recommendation to ease banking credit (RewM) and rewards in the form of compliance certificates/mass media publications (RewNM) is also included in the motivation component in social learning theory which is one of the meditational processes that influences the modeling process. The inclusion of rewards to the motivation component means that the taxpayer will imitate other taxpayer's obedient behavior if the taxpayer has a desire to do so with the given reward.

However, this study has a different result from Fochmann and Kroll (2015) which reveal that overall rewards have an adverse effect on tax compliance. This is because rewards do not have any impact on taxpayers who are given rewards and have a negative effect on taxpayers who are not given rewards. The difference in results is expected due to the use of different research methods in analyzing the effect of rewards on tax compliance. The method used in the Fochmann and Kroll research (2015) is a laboratory experiment. Other causes are suspected because the sample used is a student from Leibniz University Hannover (LLEW), while Bornman and Stack (2015b), Carillo et al. (2016) and this research use SMEs taxpayer sample.

According to the result of this study, rewards in the form of a recommendation to ease banking credit (RewM) and rewards in the form of compliance certificates/mass media publications (RewNM) has a reasonably high average value based on the respondent's answers. This means that the SMEs taxpayers in Indonesia strongly support both reward mechanism. But, rewards in the form of a recommendation to ease banking credit (RewM) have a slightly higher average value and stronger relationship with tax compliance behavior than rewards in the form of certification of compliance/mass media publications (RewNM). It means that the provision of rewards in the form of a recommendation to ease banking credit (RewM) is more favorable than rewards in the form of certification of compliance/mass media publication (RewNM). It is allegedly because rewards in the form of certification of compliance/mass media publication (RewNM) does not give a significant effect in the development of SMEs business if compared with rewards in the form of a recommendation to ease banking credit (RewM).

However, rewards in the form of a recommendation to ease banking credit (RewM) better than rewards in the form of compliance certification/mass media publication (RewNM) in increasing tax compliance turned out to be contrary to motivation crowding theory. According to motivation crowding theory, rewarding is supposed to be supportive, rather than controlling. This is because the rewards that are supportive will strengthen the intrinsic motivation of the taxpayer in fulfilling all tax obligations compared with the rewards that are controlling. As it is known, rewards in the form of recommendation to ease banking credit (RewM) are monetary and Costa-font, Jofre-Bonet, and Yen (2013) in Bornman and Stack $(2015 \mathrm{~b}, 803)$ suggest that monetary rewards will have an impact on the decrease in intrinsic motivation of the individual because it is considered to have the nature of controlling.

The difference result of this study with motivation crowding theory is supported by Fatas et al. (2015) which discloses that the taxpayer has an incentive to increase compliance with tax rules if the taxpayer perceives that the reward given is valuable in the taxpayer perspectives. Reward 
in the form of a recommendation to ease banking credit (RewM) in this research is considered more valuable than reward in the form of a certificate of compliance/publication of mass media (RewNM). It is allegedly because according to the perception of the tax reward in the form of a recommendation to ease banking credit can give an injection of additional funds to the SME's taxpayer in developing its business. As disclosed by Fatas et al. (2015) symbolic rewards such as the provision of compliance certificates/mass media publications are considered insufficient, as symbolic rewards are less likely to have a significant impact on their business.

Carillo et al. (2016) also provide arguments against the motivation crowding theory that is not always a nonmonetary reward can increase intrinsic motivation. If the taxpayer deems the reward given has a low value, then the taxpayer certainly will not change the taxpayer compliance behavior in question. Carillo et al. (2016) also support the results of this study which found a significant positive effect on the provision of compliance certificates/ mass media publications. Regarding the reward is only nonmonetary, the effect is given only valid in the short term. Therefore, Carillo et al. (2016) suggest giving rewards should be more visible and durable which means the taxpayers can enjoy the reward in real and in the long term.

\section{Enforcement Strategies and tax compliance}

The result of the study suggests that the accommodative approach has a positive effect on SMEs taxpayer compliance, whereas the deterrence approach has no positive effect on the compliance of the SMEs taxpayer. In addition, the deterrence approach is also less favored than accommodative approach by the SMEs taxpayers. This fact strengthens the test results in this study which states that taxpayers are treated with respect and courtesy. Therefore, It will give the opportunity to narrate the problem in fulfilling taxation obligations and are invited to work together in determining the solution so that the SMEs taxpayer in the future will be more obedient and provide a sense of comfort on Indonesia Tax Office. It will encourage taxpayers to not resistant to Indonesia Tax Office so that automatically taxpayers will be more responsible in fixing their mistakes constructively to comply with all tax obligations. But, if SME's taxpayer treated with disrespect and courtesy, considered as criminals/violators, submitted tax bills without confirmation, and proposed examination and investigation without knowing the condition of the taxpayer will make the taxpayer becomes uncomfortable / hate against taxation. That hate/uncomfortable feeling will eventually turn into resistance to taxation and in the long run causing noncompliance with the tax provisions.

The results of this study suggest little contradiction with the theory of planned behavior because it is not always law enforcement made by Indonesia Tax Office can inhibit noncompliance SMEs taxpayers (control beliefs). In this case, the deterrence approach is not able to give a positive influence on tax compliance behavior. Also, the results of this study also contradict Murphy (2008) because the deterrence and accommodative approach in Murphy's (2008) study has a positive effect on tax compliance. The difference is allegedly due to taxpayer awareness in Australia sampled in the Murphy (2008) study is higher than the taxpayer awareness in Indonesia. It can be seen from the tax ratio of Australia in 2015 which amounted to 28.2 is much higher than the tax ratio of Indonesia in 2015 which only stood at 10.7. The level of awareness of the tax allegedly caused taxpayers in Australia to perceive deterrence law enforcement is a natural thing done by the Australian Tax Office, while taxpayers in Indonesia, especially SMEs perceive that the enforcement of deterrence is a scary thing and gives the negative impression against Indonesia Tax Office.

The inability of the deterrence approach to improving tax compliance can be explained in Braithwaite's theory of reintegrative shaming. The theory says that deterrence law enforcement causes increased violations. The increase in violations is due to the deterrence approach raises the resentment and resilience of the individual and is likely to engage in insubordination or non-compliance with future behavior (Murphy, 2008). Explanation of the above theory is very supportive of taxpayer conditions of SMEs in Indonesia. As explained in the previous section, the level of education of SMEs in Indonesia, especially in Bali and Lombok is mostly lowly educated. However, the cause of his disobedience is presumably due to ignorance of the SMEs taxpayer on their tax obligations. As a result of ignorance of SMEs taxpayers on tax, obligations will undoubtedly have an impact on the desire to comply with tax laws.

Related to accommodative law enforcement is better/favored in improving taxpayer compliance compared with deterrence law enforcement can use the same theory, that is Braithwaite's theory of reintegrative shaming. The theory mention that the law enforcement has accommodative can affect on the reduction of violations that will be conducted because it more stimulates the perpetrator to be responsible for errors violators and make improvements that are constructive. As disclosed by Indonesia Ministry of Finance in Supriyatna (2016), many SMEs taxpayers have tax ID number, but they are reluctant to the tax administration because of being examined or imposed a fine. Indirectly, it can be concluded that the SMEs taxpayers currently have resistance to taxation. The nature of resistance is suspected to be the primary cause of low compliance of SMEs taxpayers in Indonesia. The condition of taxpayers of SMEs in Indonesia that tend to be resistant to taxation supports the results of this study that put forward the accommodative law enforcement compared to deterrence in improving SMEs taxpayer compliance.

Under these conditions, the SMEs taxpayers are included in the classification of "taxpayers who try to comply but fail" based on the tax compliance model of the ATO (Australian Tax Office) because the SMEs taxpayers intend to comply with tax regulations, but they have limited education or knowledge of taxation. Therefore, deterrence approach of law enforcement is improper conducted for taxpayers who do not know the obligation of taxation due to the low level of 
education owned or knowledge about taxation. For example, sending a letter containing that the taxpayers have committed violations of the law, and they must pay a fine by the violation that has been conducted (Tax Collection Letter) or conducting the investigation directly without a compromise. Moreover, the deterrence approach is a high cost and time-consuming process, so that is not an efficient way to apply to SMEs because of a large number of Indonesia SMEs.

\section{v. Conclusions and Limitations}

Tax knowledge is positively associated with the tax compliance behavior. Some activities providing tax knowledge that has been done by DJP so far do not have a significant impact on compliance of taxpayers SMEs allegedly because up to know Indonesian Tax Office ignore in providing general tax knowledge and only focus in delivering specific tax knowledge to the SMEs taxpayer. In addition, the low educational factor of SMEs owners is suspected to be a reason why the tax knowledge dissemination conducted by Indonesia tax office is not sufficient.

Meanwhile, both reward options, in the form of a recommendation to ease banking credit and rewards in the way of certification of compliance/publication of mass media, have a positive influence on the tax compliance behavior of SMEs. It indicates that the compliance of taxpayers of SMEs will increase if the SMEs taxpayer is given reward either in the form of a recommendation to ease banking credit or carrying of a certificate of compliance/publication of mass media. In addition, this study suggests that reward in the form of a recommendation to ease banking credit has a more significant positive effect compared to rewards in the form of certification of compliance/publication of mass media. The results of this study contradict the motivation crowding theory which states that the monetary reward will reduce the intrinsic motivation of taxpayers.

Furthermore, the deterrence enforcement strategy does not affect SMEs tax compliance behavior. According to Braithwaite's theory of reintegrative shaming, a deterrence enforcement strategy will generate hatred for Indonesia Tax Office which will lead to resistance to taxation. Such resistant nature, in the long run, will cause non-compliance behavior to the taxation provisions. In addition, accommodative enforcement strategy has a positive effect on the tax compliance behavior of SMEs. According to Braithwaite's theory of reintegrative shaming, the enforcement strategies that are accommodative give more comfort to taxpayers against Indonesia Tax Office so that comfortable feeling will encourage the taxpayer to be constructively responsible for his past disobedience and be more obedient to the future taxation provisions.

However, this study has limitations. The respondents in this study only come from the taxpayer SMEs in Bali and Lombok. The results of this study might have a different result if the research using the respondents from other regions in Indonesia. In addition, the sample used is only limited to taxpayers of SMEs who included in the category of Indonesia Government Regulation 46 of 2013 so that the results obtained are less able to explain compliance behavior of the overall SMEs taxpayers. Regarding the selection of variables, this study uses only a few variables only in explaining the behavior of SMEs tax compliance so there are still other variables that might directly or indirectly influence the behavior of tax compliance. In particular, the selection of reward variables in the form of a recommendation to ease banking credit convenience in this study is based solely on the subjective view of the authors because it has not considered the authority of related parties to realize the use of the reward in increasing the compliance of the SMEs taxpayers.

For further research, It recommends undertaking in other areas of Indonesia to compare research results and to obtain a more representative for conditions in Indonesia. Research using reward variables is still very necessary in Indonesia to provide a comprehensive figure related to whether reward strategy can be used as a national strategy in improving tax compliance, especially SMEs taxpayers. In addition, the use of research variables enforcement strategies has also not been done in Indonesia. Further research also needs to be conducted by using enforcement strategies to ensure that Braithwaite's theory of reintegrative shaming is genuinely applicable for law enforcement implementation of the SMEs taxpayers in Indonesia. Although tax knowledge variables have been widely used to explain the tax compliance behavior of SMEs in Indonesia, up to now the use of variable tax knowledge is only based on the perception of the taxpayer only. There has never research conducted to measure the tax knowledge of taxpayers accurately. For further research development, maybe is very useful to examine its effect on the desire to obey taxation laws.

Also, based on the results of this study, Indonesia Tax Office should improve the process of providing tax knowledge in the form of dissemination, tax training, visit, and content of leaflet to SMEs taxpayers. The future implementation not only focuses on providing specific tax knowledge, such as knowledge of tax rules but also add material content about general tax knowledge. This is because adding some of the material about general tax knowledge in the first is suspected to bring a positive perception of taxation. After positive perceptions arise to taxation, automatically emerges the enthusiastic feeling of the SMEs taxpayer so providing of specific tax knowledge will be easy to do and more easily understandable by the SMEs taxpayer.

To improve the compliance of SMEs taxpayers, it needs good cooperation between Indonesia Tax Office and Indonesia Ministry of Cooperatives and SMEs. One of the programs of the Indonesia Ministry of Cooperatives and SMEs is the empowerment of cooperatives and SMEs. In the program mentioned there are some facilities that can be obtained by SMEs, such as business cooperation development, financing, enhancement of capabilities and credibility, as well as ease of import for SMEs. Inserting the tax material from each activity such as the development of business cooperation and the enhancement of the capability and credibility of SMEs will certainly have an impact on increasing the significant tax compliance of SMEs. Also, financing facility provided by 
Indonesia Ministry of Cooperatives and SMEs to SMEs sector should be given to the SMEs that fulfill tax obligation.

\section{Acknowledgment}

[1] Directorate of Tax Potential, Compliance, and Revenue, Directorate General of Taxes Jakarta, Indonesia, 12190

[2] Center for Research and Community Service, Polytechnic of State Finance STAN, Banten, Indonesia

\section{References}

[1] Ananda P.R.D, 2015, "Pengaruh Sosialisasi Perpajakan, Tarif Pajak, dan Pemahaman Perpajakan terhadap Kepatuhan Wajib Pajak (Studi pada UMKM yang Terdaftar sebagai Wajib Pajak di Kantor Pelayanan Pajak Pratama Batu)", Jurnal Mahasiswa Perpajakan, 6(2).

[2] Bank Indonesia, 2015, Profil Bisnis UMKM, Jakarta: Kerjasama Lembaga Pengembangan Perbankan Indonesia dan Bank Indonesia.

[3] Bornman Marina and Stack E. M. (Lilla), 2015a, "Rewarding Tax Compliance: Taxpayers' Attitudes And Beliefs", Journal of Economic and Financial Sciences $\mid$ JEF | October 2015 8(3), 790-807.

[4] Bornman Marina dan Stack E. M. (Lilla), 2015b, "Specific rewards for tax compliance: Responses of small business owners in Ekurhuleni, South Africa", eJournal of Tax Research (2015) vol 13, no. 3, pp. 799818 .

[5] Brockmann H., Genschel P., and Seelkopf L., 2016, "Happy taxation: Increasing tax compliance through positive rewards?", Journal of Public Policy, 36(3), 381-406, doi:10.1017/S0143814X15000331.

[6] Carillo P., Castro E., and Scartascini C., 2016, "Do Rewards Work to Maintain and Increase Tax Compliance? Evidence from the Randomization of Public Goods", IDB Working Paper Series N IDBWP-794, http://www.iadb.org.

[7] Chandra Ardan A., 2016, "UMKM Tulang Punggung Ekonomi RI, Ditjen Pajak: Jangan Mau Kalah Biayai Negara Ini”, https://finance.detik.com/berita-ekonomi-bisnis/d-3342451/umkmtulang-punggung-ekonomi-ri-ditjen-pajak-jangan-mau-kalah-biayainegara-ini (accessed on 5th September 2017).

[8] Fatas E., Nosenzo D., Sefton M., and Zizzo D. J., 2015, "A Self-Funding Reward Mechanism for Tax Compliance", Discussion Paper 15-16, University of East Anglia, Centre for Behavioural and Experimental Social Science, Norwich, Retrieved October 30, 2015.

[9] Fochmann M. dan Kroll E.B., 2015, "The Effects of Rewards on Tax Compliance Decisions", Journal of Economic Psychology (2015), doi: http://dx.doi.org/10.1016/j.joep.2015.09.009.

[10] Ghozali I., 2016, "Aplikasi Analisis Multivariete Dengan Program IBM SPSS 23 Edisi 8", Semarang: Badan Penerbit Universitas Diponegoro.

[11] Iskandar and Andriani A. F., 2017, "Pengaruh Reward, Pemeriksaan Pajak, Dan Penalti Terhadap Peningkatan Kepatuhan Wajib Pajak Orang Pribadi Di Indonesia", jurnal.pknstan.ac.id Vol 3 (2016), Edisi Maret [Online] ISSN (e-ISSN) : 2581-0839.

[12] James S. and Alley C., 2002, "Tax Compliance, Self-Assessment and Tax Administration", Journal of Finance and Management in Public Services, Volume 2 Number 2.

[13] Kirchler E., Niemirowski A., and Wearing A., 2006, "Shared subjective views, intent to cooperate and tax compliance: Similarities between Australian taxpayers and tax officers", Journal of Economic Psychology, 27(4), $502-517$.

[14] Masruroh S. dan Zulaikha, 2013, "Pengaruh Kemanfaaatan NPWP, Pemahaman Wajib Pajak, Kualitas Pelayanan, Sanksi Perpajakan Terhadap Kepatuhan Wajib Pajak (Studi Empiris pada WP OP di Kabupaten Tegal)", Diponegoro Journal of Accounting, pp.435-449.

[15] Mir'atusholihah, Kumadji, Srikandi, and Ismono B., 2014, "Pengaruh Pengetahuan Perpajakan, Kualitas Pelayanan Fiskus Dan Tarif Pajak Terhadap Kepatuhan Wajib Pajak (Studi Pada Wajib Pajak UMKM Di
Kantor Pelayanan Pajak Pratama Malang Utara)", Jurnal Mahasiswa Perpajakan Vol 3, No 1 (2014), http://perpajakan.studentjournal.ub. ac.id/.

[16] Mukasa J., 2011, "Tax Knowledge, Perceived Tax Fairness And Tax Compliance In Uganda The Case Of Small And Medium Income Taxpayers In Kampala Central Division", A Research Dissertation Submitted to the School of Graduate Studies in Partial Fulfillment of the Requirements for the Award of a Degree of Master of Science in Accounting and Finance of Makerere University.

[17] Murphy K., Bradford B. and Jackson J., 2016, "Motivating compliance behavior among offenders: Procedural justice or deterrence?", Criminal Justice and Behavior, 43(1), pp.102-118.

[18] Murphy K., 2008, "Enforcing Tax Compliance: To Punish or Persuade?", Economic Analysis \& Policy, Vol. 38 No. 1, March 2008. DOI: 10.1016/S0313-5926(08)50009-9, Source: RePEc.

[19] Oladipupo A.O. and Obazee U., 2016, "Tax Knowledge, Penalties and Tax Compliance in Small and Medium Scale Enterprises in Nigeria", iBusiness 8, 1-9, http://dx.doi.org/10.4236/ib.2016.81001

[20] Ortega D. and Sanguinetti P., 2013, "Deterrence and reciprocity effects on tax compliance: experimental evidence from Venezuela". In II Jornadas Iberoamericanas de Financiación Local (La Plata, 2013).

[21] Palil M. R., 2010, "Tax Knowledge And Tax Compliance Determinants In Self Assessment System In Malaysia", A thesis submitted to The University of Birmingham for the degree of Doctor of Philosophy.

[22] Palil M. R., 2013, "The Perception of Tax Payers on Tax Knowledge and Tax Education with Level of Tax Compliance: A Study the Influences of Religiosity", ASEAN Journal of Economics, Management and Accounting 1 (1): 118-129, (June 2013), ISSN 2338-9710.

[23] Purnaditya R. R. and Rohman A., 2015, "Pengaruh Pemahaman Pajak, Kualitas Pelayanan dan Sanksi Pajak Terhadap Kepatuhan Pajak (Studi Empiris Pada WP OP Yang Melakukan Kegiatan Usaha Di KPP Pratama Semarang Candisari)". Diponegoro Journal Of Accounting Volume 4, Nomor 4, Tahun 2015.

[24] Rachman F. F., 2017, "Sri Mulyani: Setoran Pajak Rendah Sekali, Tak Bisa Diterima!", Detik.com [Online], https://finance.detik.com/beritaekonomi-bisnis/3557665/sri-mulyani-setoran-pajak-rendah-sekali-takbisa-diterima (accessed on 5th September 2017).

[25] Redae R. B. and Sekhon S., 2016, "Taxpayers' Knowledge and Tax Compliance Behavior in Ethiopia: A Study of Tigray State", International Journal of Management and Commerce Innovations Vol. 3, Issue 2, pp: (1090-1102).

[26] Saad N., 2014, "Tax Knowledge, Tax Complexity, and Tax Compliance: Taxpayer's View", Procedia - Social and Behavioral Sciences 109(2014), $1069-1075$

[27] Sawitri A. A., 2017a, "Sri Mulyani Paparkan Hasil Kerja Tim Reformasi Pajak", Tempo.co [Online], https://m.tempo.co/read/news/2017/04/03/ 090862258 /sri-mulyani-paparkan-hasil-kerja-tim-reformasi-pajak (accessed on 5th September 2017).

[28] Sawitri A. A., 2017b, "Kementerian Koperasi: Baru 397 Ribu UMKM Bayar Pajak dari 59 Juta”, Tempo.co [Online], https://bisnis.tempo.co/ $\mathrm{read} /$ news/2017/08/29/090904372/kementerian-koperasi-baru-397-ribuumkm-bayar-pajak-dari-59-juta (accessed on 5 September 2017).

[29] Suntono dan Kartika A., 2015, "Pengaruh Pemahaman Peraturan Pajak dan Pelayanan Aparat Pajak Terhadap Kepatuhan Wajib Pajak dengan Preferensi Risiko sebagai Variabel Moderasi", Dinamika Akuntansi, Keuangan, dan Perbankan, Mei 2015 Hal 29-38, Vol 4, No. 1, ISSN: 1979-4878.

[30] Supriyatna I., 2016, "Menkeu: Agar Bisa Ikut Pengampunan Pajak, UMKM Harus Segera Rapikan Administrasi Perpajakan", Kompas.com [Online].http://bisniskeuangan.kompas.com/read/2016/07/18/132100926 /menkeu.agar.bisa.ikut.pengampunan.pajak.umkm.harus.segera.rapikan. administrasi.perpajakan (accessed on 25th November 2017).

[31] Tanko M. B., 2015, "Tax Law Enforcement: Practice and Procedure", Research Journal of Finance and Accounting ISSN 2222-1697 (Paper) ISSN 2222-2847 [Online] Vol.6, No.7, 2015. 